\title{
Pituitary adenoma apoplexy in pregnancy: Case report and literature review
}

\author{
LUCIAN GHEORGHE POP ${ }^{1}$, AURORA ILIAN ${ }^{2}$, TIBERIU GEORGESCU ${ }^{1,3}$, \\ NICOLAE BACALBASA ${ }^{3,4}$, IRINA BALESCU ${ }^{5}$ and OANA DANIELA TOADER ${ }^{1,3}$
}

\author{
${ }^{1}$ Department of Obstetrics and Gynecology, National Institute of Mother and Child Care, 400012 Bucharest; \\ ${ }^{2}$ Department of Obstetrics and Gynecology, 'Victor Babes' University of Medicine and Pharmacy, 300014 Timisoara; \\ ${ }^{3}$ Department of Obstetrics and Gynecology, 'Carol Davila' University of Medicine and Pharmacy, 020021 Bucharest; \\ ${ }^{4}$ Department of Visceral Surgery, 'Dan Setlacec' Center of Gastrointestinal Diseases and Liver Transplantation, \\ 'Fundeni' Clinical Institute, 022328 Bucharest; ${ }^{5}$ Department of Surgery, \\ 'Ponderas' Academic Hospital, 021188 Bucharest, Romania
}

Received July 27, 2021; Accepted August 26, 2021

DOI: $10.3892 /$ etm.2022.11143

\begin{abstract}
Gestational pituitary apoplexy is an extremely rare condition. It is characterised by an unexpected headache, vomiting, nausea, and visual disturbances. Pituitary apoplexy in pregnancy and postpartum is a challenging diagnosis with symptoms overlapping multiple conditions. There is a limited number of articles presenting cases or case series of gestational pituitary apoplexy. This is a potentially life-threatening emergency which requires a high index of suspicion for its diagnosis. This article presents a case of postpartum pituitary apoplexy and outlines the current stage of clinical, imagistic diagnosis and management options. A 26-year-old primipara was submitted to a Caesarean section, with no perioperative incidents. Forty-eight hours later she reported the apparition of frontal and temporal throbbing headaches, nausea, photophobia, and she was diagnosed with a pituitary tumor measuring $33 \times 10.5 \times 15.5 \mathrm{~mm}$. Although initially conservative treatment was proposed, the clinical outcome was not favourable, thus the patient was submitted to endoscopic transsphenoidal resection. The histopathological studies demonstrated the presence of a pituitary macroadenoma. At the 2-year follow-up, the patient is free of disease. Although it represents an extremely rare condition, gestational pituitary apoplexy should be suspected whenever headache and neurological disorders such as nausea and photophobia are reported during the postpartum period.
\end{abstract}

Correspondence to: Dr Nicolae Bacalbasa, Department of Obstetrics and Gynecology, 'Carol Davila' University of Medicine and Pharmacy, 37 Dionisie Lupu Street, 020021 Bucharest, Romania E-mail: nicolae_bacalbasa@yahoo.ro

Key words: pituitary apoplexy, adrenal insufficiency, headaches, pregnancy, puerperium

\section{Introduction}

Migraines are a common post-surgical and puerperal complaint, consistent with a myriad of etiologies, encompassing physiological changes, hormonal modifications, peri-surgical procedures and unknown prenatal conditions. The primary causes include tension-type headaches, cluster headaches and other trigeminal nerve cephalgia $(1,2)$. Secondary headaches are are less common but can have severe consequences with significant mortality and morbidity if they are overlooked. Diagnosis of a secondary cause is a daunting task, taking into account that headache can be the only symptom of multiple conditions such as postdural puncture headache (PDPH), pneumocephalus, preeclampsia and eclampsia, meningitis, cerebral venous thrombosis, ischemic or hemorrhagic stroke, subarachnoid haemorrhage, reversible cerebral vasoconstriction syndromes, posterior reversible leukoencephalopathy syndrome and pituitary adenoma. Therefore, a high index of suspicion is required, and a low threshold for a neuroimaging investigation when dealing with postpartum headaches is needed $(3,4)$. Needless to say, any suspicion of a secondary headache should be investigated by a multidisciplinary team due to the challenges posed by such wide-ranging conditions. Although pituitary adenoma is seldom a differential diagnosis in pregnancy and postpartum headache, it is part of a differential diagnosis when associated with visual loss. Ocular visual impairment is the next common symptom in pituitary adenoma after headache. We present the case of postpartum pituitary apoplexy, following an emergency Caesarean section.

\section{Case report}

After obtaining approval of the Ethics Committee of the National Institute of Mother and Child Care (Bucharest, Romania) (no. 25/2019), data of the patient were reviewed and presented in the current case report. A 26-year-old primigravida, 40 weeks gestation, was admitted to our maternity ward at the National Institute of Mother and Child Care, in 
spontaneous labour. She delivered a 3,150 g female baby, Apgar score 9, through Category II Caesarean section for failure to progress. The anaesthetist performed spinal anaesthesia with bupivacaine and fentanyl. Caesarean section was routine and pain-free, with an estimated blood loss of approximately $400 \mathrm{ml}$. Pre-delivery haemoglobin was $11.5 \mathrm{~g} / \mathrm{dl}$ and at post-delivery the value was slightly decreased at $10.2 \mathrm{~g} / \mathrm{dl}$. She had no prior medical history, and her antenatal care was uneventful. The immediate postpartum period was unremarkable. The patient remained alert and orientated with normal vital signs. The following day she was transferred to the postnatal ward. Approximatively $48 \mathrm{~h}$ post-delivery she presented frontal and temporal throbbing headaches, nausea, and photophobia, but no nuchal rigidity or backache. On examination, she presented left ptosis, anisocoria, incomplete 3rd cranial nerve paresis and normal fundoscopy. Vital signs were: temperature, $38^{\circ} \mathrm{C}$; blood pressure, $135 / 75 \mathrm{mmHg}$; heart rate, 68 beats per minute; and significant polyuria $(3.9 \mathrm{cc} / \mathrm{kg} / \mathrm{h})$. An urgent neurological exam followed by an endocrinological appointment was required and indicated no signs of meningeal irritation or neurological deficiency. Consistent with her clinical examination, polyuria and polydipsia, pituitary apoplexy was a presumptive diagnosis and a magnetic resonance imaging (MRI) examination was performed. Head MRI showed a cystic pituitary tumour with a $33 \mathrm{~mm}$ transverse diameter, $10.5 \mathrm{~mm}$ anteroposterior, $15.5 \mathrm{~mm}$ craniocaudal. The tumour was bulging bilaterally in the cavernous sinus (into the sella turcica), encasing partially the right carotid artery. The tumour was in contact with the optic chiasm without signs of displacement or compression. The MRI diagnosis was of a pituitary macroadenoma, possible Rathcke cleft cyst (Fig. 1). Electrolytic and endocrinological tests were carried out, the results being displayed in Table I (day 4 post-delivery, 8 a.m.) showing hypopituitarism involving corticotrophin, lactotrophic and thyrotropin dysfunction with hyponatremia and hypochloremia.

Treatment with intravenous dexamethasone, thyroxin $50 \mu \mathrm{g}$, fluid and electrolyte replacement was initiated immediately. On the following day, a multidisciplinary meeting took place with obstetricians, anaesthesiologists, endocrinologists, neurologists and neurosurgeons in order to define a postpartum management plan. Initially, conservative management was started but as her condition worsened with a deteriorating level of conciseness, treatment was converted to surgical decompression. Endoscopic transsphenoidal pituitary surgery was performed to remove the $3 \times 2 \times 1 \mathrm{~cm}$ encapsulated tumour. Histopathology result showed a non-functional pituitary macroadenoma. Post-surgical clinical examination revealed normal neurological condition while the oculomotor paresis was wholly resolved. Two years after surgery, the patient is well under hormone replacement therapy. Currently, she is receiving oral medication, prednisolone $50 \mu \mathrm{g} / \mathrm{day}$, thyroxine $75 \mu \mathrm{g}$ and cycloprogynova (estradiol, norgestrel).

\section{Discussion}

Pituitary adenomas represent approximatively $10-15 \%$ of all intracranial tumours. Microadenomas are tumours of less than $10 \mathrm{~mm}$ while macroadenomas include tumours larger than $10 \mathrm{~mm}$. Giant adenomas are more than $40 \mathrm{~mm}$ in size.
Table I. Electrolytic and endocrinological blood test results of the patients with pituitary apoplexy.

\begin{tabular}{lcc}
\hline Parameter & Value & Normal range \\
\hline Cortisol & $43.1 \mathrm{nmol} / \mathrm{l}$ & $123-626$ \\
Adrenocorticotropic hormone & 25.14 & $7.0-63$ \\
(ACTH) & & \\
Prolactine & $162 \mathrm{nmol} / 1$ & $64-395$ \\
Thyroid-stimulating hormone & $0.211 \mathrm{mIU} / 1$ & $0.46-4.68$ \\
(TSH) & & \\
T3 & $1.19 \mathrm{nmol} / 1$ & $1.49-2.60$ \\
Free T4 & $8.57 \mathrm{pmol} / 1$ & $10.0-28.2$ \\
Cl & 92.00 & $97-108$ \\
K & $4.4 \mathrm{mmol} / 1$ & $3.5-5.1$ \\
Na & $122 \mathrm{mmol} / 1$ & $136-145$ \\
Serum osmolality (mOs/kg) & 269.9 & $280-300$
\end{tabular}

Between 14 and 54\% are non-functional adenomas while the rest secrete excess hormones: 8-12\% growth hormones, 2-6\% release adrenocorticotropic hormone and less than $1 \%$ secrete thyrotropin (1-6). Despite solid research regarding pituitary adenoma, the pathogenesis remains unknown $(5,6)$. Because of the associated hypertrophy of lactotrophic cells and the increase in normal pituitary volume, pregnancy is also considered a risk factor for pituitary apoplexy (7). Hereditary transmission is responsible for less than $5 \%$ of the cases (8). The pituitary gland also represents a location for metastatic deposits in $0.1-0.2 \%$ of cases, the most common primary tumours being represented by lung and breast (9-11). Pituitary apoplexy is a rare endocrinological emergency, which can occur without any eliciting factors. Nevertheless, in most cases, there are known risk factors such as major surgery, hypertension, coagulopathies or postpartum haemorrhage (Sheehan syndrome). Sheehan syndrome is the most common reason of postpartum pituitary insufficiency, which is caused by a massive blood loss during delivery or during the early postpartum period. Whenever Sheehan syndrome is suspected, two conditions should be part of the differential diagnosis, postpartum necrosis of a preexisting hypophyseal tumor and lymphocytic hypophysitis.

Diagnosis of postpartum apoplexy is a challenging one as many patients do not have any pituitary history. The most commonly encountered symptom is headache, which is frequently associated with various pathological conditions. Alongside headache, blurred vision, diplopia, photophobia, or bitemporal hemianopsiavision loss have all been reported in pituitary adenoma. Symptomatology in cases of known adenoma is due to a sharp increase in size, which is an estrogen-driven one (9). This will raise intrasellar pressure causing compression and necrosis of the pituitary gland with subsequent pituitary insufficiency. Increased intracranial pressure leads to neurologic symptoms such as nausea and vomiting. Quite often, patients can lose their consciousness or have at least a mild degree of lethargy (10). The clinical picture can mimic multiple neurological conditions, and this is why a high index of suspicion should prompt investigation for pituitary apoplexy. 


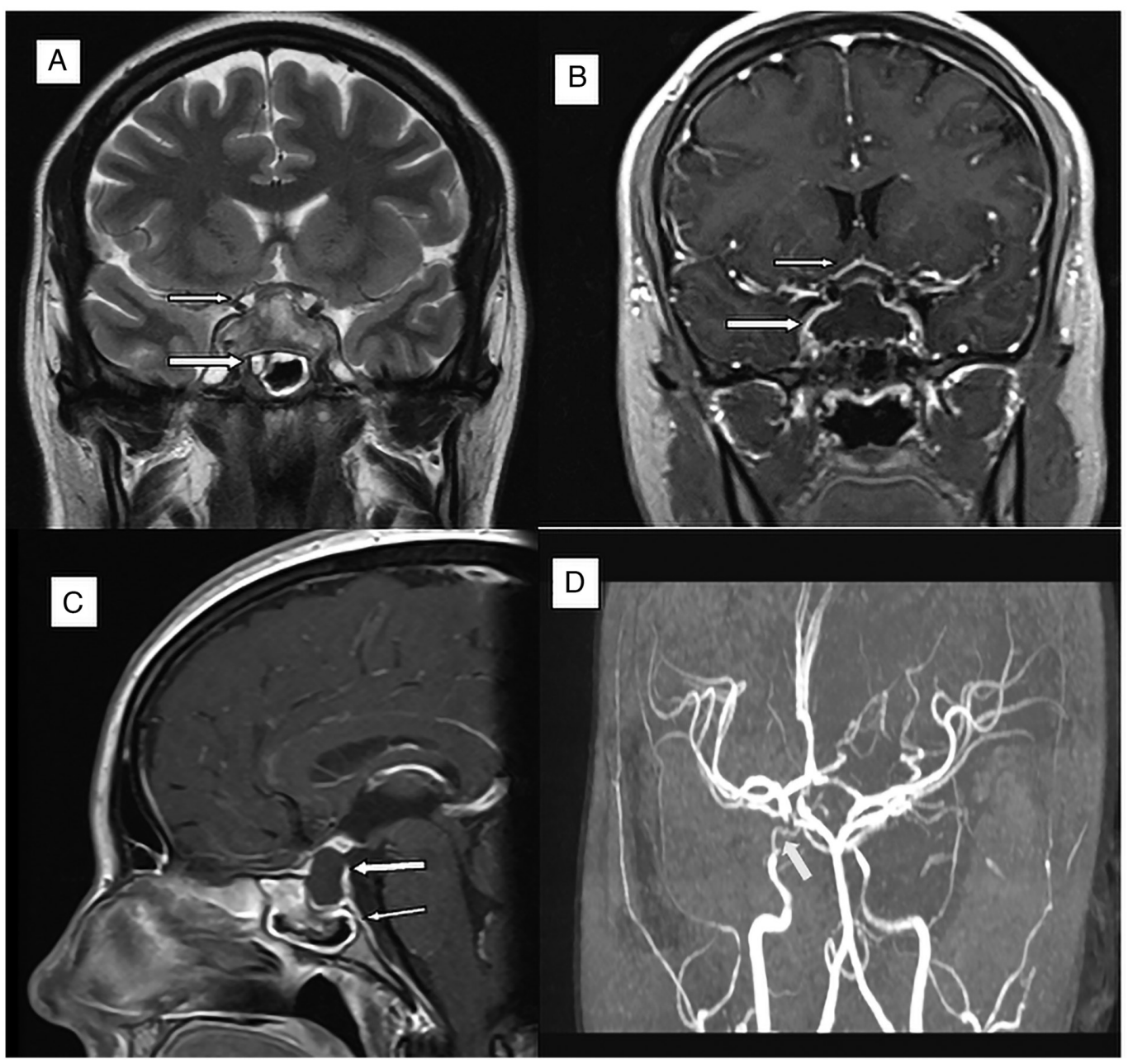

Figure 1. Magnetic resonance imaging (MRI) images of our case. (A) T2-weighted coronal image showing a cystic pituitary tumor (thick arrow) compressing the optic chiasm (thin arrow). (B) Post-contrast T2 showing a cystic pituitary mass (thick arrow) compressing the optic chiasm (thin arrow). (C) Sagittal-cystic mass (thick arrow), and thickened muscosa of the sphenoidal sinus (thin arrow). (D) Bilateral reduction of the intracavernous diameter of the carotidian artery, more prominent on the right side (arrow).

When it comes to the laboratory tests which are required in order to provide a positive diagnosis, it should be emphasized that pregnancy is a condition presenting with hormonal imbalance making interpretation of endocrine and dynamic tests more difficult. Increased levels of prolactin are normal during pregnancy, although low levels of prolactin can suggest pituitary insufficiency (11). Patients with pituitary apoplexy and low prolactin levels are the most affected and it is unlikely that they will have a successful post-surgical recovery (12). Adrenocorticotropic hormone (ACTH) deficiency is commonly present in pituitary apoplexy, but thyroid-stimulating hormone (TSH), growth hormone (GH), and gonadotropin deficiency have also been reported. Adrenal insufficiency is the most serious complication as it is life-threatening (10). Hyponatremia complicates pituitary apoplexy as it is a sign of adrenal insufficiency or of the syndrome of inappropriate antidiuretic hormone (ADH) secretion (13). Therefore, whenever pituitary apoplexy is part of a working diagnosis, a full endocrine (cortisol, ACTH, prolactine, follicle-stimulating hormone, luteinizing hormone, insulin-like growth factor 1, free T4, TSH) and blood assessment (full blood count, glycemia, electrolytes (serum sodium and potassium), and renal and liver function) should be performed urgently.
The gold standard for pituitary apoplexy diagnosis is MRI as it confirms the diagnosis in over $90 \%$ of cases. On T1-weighed images, haemorrhage typically manifests with hyperintensity related with the rest of the brain (14). MRI and MR angiogram techniques also help to differentiate an aneurism from pituitary apoplexy. MRI is safe during pregnancy, and to date no damaging fetal effects have been reported. MRI is the investigation of choice compared with any other ionising technique. The majority of radiologist avoid using gandolinum in pregnancy as it crosses the placenta, enters fetal circulation, is eliminated by kidneys and secreted in amniotic fluid. To date, no deleterious effects have been reported regarding using gandolinum in pregnancy (15).

Based on the review of the literature [Table II $(4,7,10,13,16-50)]$, we found 48 cases of pregnancy-related pituitary tumour apoplexy. Statistical analysis of the gestational age at diagnosis showed an average value of 27.9 weeks (range 10-39 weeks) with the caveat that three of these cases, including ours, occurred during the postpartum period. Extremely rare, pituitary apoplexy can occur even in the first trimester as reported by Janssen et al at 10 weeks of gestation (16). Prolactinoma (21 cases) was the most common tumor encountered and in many occasions in patients who 
Table II. Outcomes of pregnancy-related pituitary tumour apoplexy cases submitted to surgical decompression during pregnancy.

\begin{tabular}{|c|c|c|c|c|c|c|}
\hline Authors (ref.) & Year & $\begin{array}{c}\text { Age } \\
\text { (years) }\end{array}$ & Diagnosis & Onset & Treatment & Outcome \\
\hline Oguz et al (17) & 2020 & 26 & Macroprolactinoma & 22 weeks & Surgical & Hypothyroidism \\
\hline Jemel et al (27) & 2019 & 37 & Prolactinoma & 32 weeks & Surgical & Hypothyroidism \\
\hline Bachmeier et al (4) & 2019 & 30 & Macroadenoma & $36+5$ weeks & $\begin{array}{l}\text { Surgical } \\
\text { decompression }\end{array}$ & Full recovery \\
\hline Annamalai et al (36) & 2017 & 25 & Microprolactinoma & $37+4$ weeks & $\begin{array}{l}\text { Conservative } \\
\text { treatment }\end{array}$ & Full recovery \\
\hline O'Neal (32) & 2017 & 27 & Macroadenoma & 29 weeks & $\begin{array}{l}\text { Surgical } \\
\text { decompression }\end{array}$ & Diabetes insipidus \\
\hline Galvao et al (46) & 2017 & 30 & Macroprolactioma & 28 weeks & $\begin{array}{l}\text { Conservative } \\
\text { treatment }\end{array}$ & $\mathrm{N} / \mathrm{A}$ \\
\hline Abraham et al (22) & 2016 & 32 & Enlarged pituitary & 23 weeks & $\begin{array}{l}\text { Surgical } \\
\text { decompression }\end{array}$ & $\mathrm{N} / \mathrm{A}$ \\
\hline Grand'Maison et al (7) & 2015 & 33 & Macroadenoma & 39 weeks & Conservative & Full recovery \\
\hline Watson (42) & 2015 & 33 & Macroadenoma & $37+4$ weeks & Conservative & Full recovery \\
\hline Querol Ripoll et al (34) & 2015 & 37 & $\begin{array}{l}\text { Cystic } \\
\text { microprolactinoma }\end{array}$ & 24 & Surgery & Panhypopituitarism \\
\hline De Ycaza et al (47) & 2015 & 26 & Macroprolactinoma & 28 weeks & Conservative & Partial hypopituitarism \\
\hline Bedford et al (48) & 2015 & 35 & Adenoma & N/A & $\mathrm{N} / \mathrm{A}$ & N/A \\
\hline Piantanida et al (9) & 2014 & 27 & Adenoma & 35 weeks & Surgery & Central hypothyroidism \\
\hline Hayes et al (26) & 2014 & 41 & Microprolactinoma & 18 weeks & Surgery & Full recovery \\
\hline Tandon et al (49) & 2014 & 27 & Prolactinoma & 36 weeks & Surgery & $\begin{array}{l}\text { Temporary diabetus } \\
\text { insipidus (DI) }\end{array}$ \\
\hline Chegour and El Ansari (38) & 2014 & 29 & Prolactinoma & 19 weeks & Conservative & $\begin{array}{l}\text { Resolution of visual } \\
\text { visual symptoms }\end{array}$ \\
\hline Mathur (51) & 2014 & 34 & $\begin{array}{l}\text { Pituitary apoplexy } \\
\text { spinal anaesthesia }\end{array}$ & Postpartum & $\begin{array}{l}\text { Surgical } \\
\text { decompression }\end{array}$ & $\begin{array}{l}\text { Reversible cerebral } \\
\text { vasoconstrictive } \\
\text { syndrome; Full recovery }\end{array}$ \\
\hline Kita et al (28) & 2012 & 26 & Macroadenoma & 26 weeks & $\begin{array}{l}\text { Surgical } \\
\text { decompression }\end{array}$ & Diabetus inspidus \\
\hline Witek et al (35) & 2012 & 25 & Macroprolactinoma & 19 weeks & $\begin{array}{l}\text { Surgical } \\
\text { decompression }\end{array}$ & Full recovery \\
\hline Janssen et al (16) & 2012 & 27 & Prolactinoma & 10 weeks & Conservative & $\begin{array}{l}\text { Partial recovery; } \\
\text { Adrenal insufficiency }\end{array}$ \\
\hline Couture et al (39) & 2012 & 37 & Microprolactinoma & 19 weeks & Conservative & Full recovery \\
\hline Tonda and Rizvi (45) & 2011 & 22 & Hypophysitis & 36 weeks & Conservative & Panhypopituitarism \\
\hline Murao et al (44) & 2011 & 35 & Normal pituitary & 39 weeks & Conservative & Panhypopituitarism \\
\hline Bamfo et al (37) & 2011 & 31 & Macroadenoma & 23 weeks & Conservative & Full recovery \\
\hline Iuliano and Laws (40) & 2011 & 28 & Acroadenoma & 29 weeks & Conservative & Full recovery \\
\hline Ginath and Golan (24) & 2010 & 31 & Prolactinoma & 39 weeks & Surgery & Full recovery \\
\hline Perotti and Dexter (33) & 2010 & 29 & $\begin{array}{l}\text { Pituitary } \\
\text { macroadenoma }\end{array}$ & Postpartum & Surgery & Panhypopituitarism \\
\hline Parihar et al (41) & 2009 & 20 & Macroprolactinoma & 20 weeks & $\begin{array}{l}\text { Surgical } \\
\text { decompression }\end{array}$ & Full recovery \\
\hline Okafor et al (21) & 2009 & 30 & Macroprolactinoma & 33 weeks & Conservative & Death \\
\hline Gheorghiu et al (50) & 2009 & 33 & Nelson syndrome & 22 weeks & Conservative & Diabetus inspidus \\
\hline Krull et al (13) & 2010 & 7 & Normal pituitary & 7 weeks & Conservative & $\begin{array}{l}\text { Miscarriage 9th week; } \\
\text { Ischemic encephalopathy } \\
\text { whichwas resolved; } \\
\text { Persistent } \\
\text { panhypopituitarism and } \\
\text { DI }\end{array}$ \\
\hline
\end{tabular}


Table II. Continued.

\begin{tabular}{|c|c|c|c|c|c|c|}
\hline Authors (ref.) & Year & $\begin{array}{l}\text { Age } \\
\text { (years) }\end{array}$ & Diagnosis & Onset & Treatment & Outcome \\
\hline Atmaca et al (18) & 2006 & 33 & $\begin{array}{l}\text { Macroadenoma } \\
\text { (GH-oma) }\end{array}$ & 29 weeks & $\begin{array}{l}\text { Surgical } \\
\text { decompression }\end{array}$ & Panhypopituitarism \\
\hline Paech (20) & 2006 & 21 & Macroadenoma & Postpartum & Conservative & Full recovery \\
\hline Fujimaki (43) & 2005 & 23 & Hypophysitis & 34 weeks & Conservative & Adrenal insufficiency \\
\hline De Heide et al (10) & 2004 & 26 & Macroprolactinoma & 23 weeks & Conservative & Panhypopituitarism \\
\hline Gondim et al (25) & 2003 & 29 & Macroadenoma & 30 weeks & $\begin{array}{l}\text { Surgical } \\
\text { decompression }\end{array}$ & Full recovery \\
\hline Lee and Pless (30) & 2003 & 26 & Hypophysitis & 28 weeks & $\begin{array}{l}\text { Surgical } \\
\text { decompression }\end{array}$ & Full recovery \\
\hline Freeman et al (23) & 1992 & 22 & Prolactinoma & 32 weeks & $\begin{array}{l}\text { Surgical } \\
\text { decompression }\end{array}$ & Diabetus inspidus \\
\hline Lunardi et al (19) & 1991 & 21 & $\begin{array}{l}\text { Macroadenoma } \\
\text { (GH-oma) }\end{array}$ & 24 weeks & $\begin{array}{l}\text { Surgical } \\
\text { decompression }\end{array}$ & Full recovery \\
\hline O'Donovan et al (31) & 1986 & 37 & Macroprolactinoma & 8 weeks & $\begin{array}{l}\text { Left } \\
\text { frontotemporal } \\
\text { craniotomy }\end{array}$ & $\begin{array}{l}\text { Left-sided cranial nerve } \\
\text { palsy }\end{array}$ \\
\hline Lamberts et al (29) & 1979 & N/A & Prolactinoma & 23 weeks & $\begin{array}{l}\text { Surgical } \\
\text { decompression }\end{array}$ & $\begin{array}{l}\text { Resolution of visual } \\
\text { symptoms }\end{array}$ \\
\hline Our case & 2020 & 26 & Macroadenoma & Postpartum & $\begin{array}{l}\text { Surgical } \\
\text { decompression }\end{array}$ & Panhypoituitarism \\
\hline
\end{tabular}

DI, diabetus insipidus; N/A, not available.

were under treatment. This is in line with published literature where prolactinoma is present in approximately $50 \%$ of all cases (17). There were 17 cases of non-secreting adenoma, 2 cases of GH-oma, 3 cases of hypophysitis, one case of Neslon syndrome, one case of enlarged pituitary gland, one case of pituitary apoplexy followed by reversible cerebral vasoconstrictive syndrome and one case of normal size pituitary gland but with a histopathological diagnosis of adenoma post-surgery (Table II). In many hospitals, current practice is to halt cabergoline/bromocriptine, although there is no robust evidence for this decision (17). Onset of symptoms in a patient with a known adenoma should trigger imagistic investigations that will clarify if this is a case of progressive adenoma or a different aetiology. A real challenge is the diagnosis of pituitary apoplexy in patients with unknow adenomas. Precious time can be lost by interpreting a headache as a migraine type. There are several cases, including ours, where pituitary apoplexy was the main cause $(9,10,18,19,51)$. Migraine is rather an exclusion diagnosis, and for this reason, failure to consider a different diagnosis can cause significant mortality and morbidity. Only a small proportion of these cases were diagnosed during the postpartum period. Symptoms such as dizziness, headache, nausea and vomiting are thought to be connected to surgery and anaesthesia and not necessarily to neurological or endocrinological conditions. This is why it is important to pay attention to 'red flags' to avoid diagnostic errors.

Mathur et al described a case of postpartum pituitary apoplexy following spinal anaesthesia which was treated conservatively. Ten days later, continuous thunderclap headache prompted computed tomography (CT) angiography and contrast-enhanced MRI. Images were suggestive of stenoses in the anterior and right middle cerebral arteries as well as of the vertebrobasilar segments. Based on the clinical picture, history and imagistic investigation, the final diagnosis was of reversible cerebral vasoconstrictive syndrome (RCVS). The patient's condition improved after treatment with nimodipine and lamotrigine (51). Perotti and Dexter described a postpartum pituitary apoplexy after a spontaneous delivery. The mother presented with headache, nausea and photophobia. A contrast CT scan showed a $6.1 \times 3.9 \times 5.2 \mathrm{~cm}$ giant macroadenoma which required trans-sphenoidal craniotomy (33). Paech et al published a case of a 15x13×12 mm macroadenoma, which was diagnosed post-delivery. Similar to our patient, this case presented initially with drooping eyelid and dilated left pupil. She reported no headaches, facial weakness or any other neurological symptom. She was managed conservatively and 14 months after her first presentation she delivered a second baby. Pregnancy course and postpartum period were unremarkable (20). We only found one case of pregnancy pituitary adenoma, which ended with the demise of the patient. A 30-year-old patient diagnosed with pituitary adenoma at 24 weeks of gestation was prescribed bromocriptine with a plan for a postnatal neurosurgery. Following a preterm delivery at 35 weeks through Caesarean section she developed hypertension, acute encephalopathy and fatal cardiac arrest on day three postpartum (21).

At this moment, there is no robust evidence regarding the best management. This is a matter of debate between surgical vs. a conservative method. Whenever pituitary 
apoplexy occurs in pregnancy, initial treatment consists of fluid, electrolyte, and hormonal replacement. In a normal pregnancy, cortisol levels are two to four times above the average values due to placental function, pituitary production, and changes in hormone-binding globulin. Criteria that are used outside pregnancy cannot be used during gestation or early puerperium. Meanwhile, it should be emphasized that adrenal insufficiency is a life-threatening condition. Therefore, glucocorticoid input is vital and should be started as soon as pituitary apoplexy is suspected. UK guidelines for pituitary apoplexy recommend 100-200 mg hydrocortisone as intravenous bolus, followed by $2-4 \mathrm{mg} / \mathrm{h}$ intravenous continuous administration or by $50-100 \mathrm{mg}$ every six hours by intramuscular injection. Once the acute episode is overcome, the steroid regimen should be reduced to a standard maintenance dose of 20-30 mg (52).

After stabilization of the patient, the critical question is whether surgery is necessary or medical treatment is an option. Due to the rarity of this condition, there are no randomized control trials only case reports and case series being reported to date. It is practical to carry on with medical treatment, and if there is no improvement or a deterioration in clinical condition then surgery must be performed. In seriously ill patients, the current literature and expert opinion favors surgical decompression. Analysis of 22 cases from Table II showed that surgical decompression in pregnancy is safe without any teratogenic effects $(4,9,17-19,22-35,51)$. The majority of cases were able to deliver in the late 3rd trimester as was exemplified by Oguz et al and Querol Ripoll et al; the authors showed that surgery performed even in the second trimester does not alter pregnancy course $(17,34)$. Analysis of cases treated conservatively showed that this is a viable and safe option in a patient without visual field defects. Overall, in 16 cases there was full recovery of endocrinological function and in 21 cases, various degree of insufficiency ranging from diabetes insipidus to panhypopituitarism and cranial nerve palsy being encountered $(4,7,9,19,24,26,29,30,35-42,51)$. For 11 cases, long-time consequences were not noted. Most patients, while they were receiving multiple medications, reported a good quality of life $(9,10,16,18,31-34,43-45)$.

In conclusion, to the best of our knowledge, this is the third case reported of postpartum gestational pituitary apoplexy arising in the context of a previous macroprolactinoma which shows the rarity of this condition. To date, there are no clear guidelines regarding the most efficacious treatment for pituitary apoplexy. This issue is more complex in pregnancy. As pituitary apoplexy is unpredictable, it is imperative to inform patients with known adenoma about apoplexy symptoms. Antenatal care should be individualised with urgent MRI and visual field test if the situation requires. A high index of suspicious, a multidisciplinary approach and good clinical judgement can ensure the best decision in terms of management and patient counselling.

In pregnancy and puerperium alike, headache is common and although it is usually benign can herald serious and detrimental intracranial issues.

\section{Acknowledgements}

Not applicable.

\section{Funding}

No funding was received.

\section{Availability of data and materials}

Further information regarding the case presentation is available upon request.

\section{Authors' contributions}

NB contributed to the conception of the study, collected, analyzed and interpreted data from the literature and critically revised the manuscript. IB contributed to the conception of the study, performed the literature research, drafted the manuscript and is responsible for confirming the authenticity of all the raw data. LGP contributed to the conception of the study, performed the literature research, drafted the manuscript and is responsible for confirming the authenticity of all the raw data; ODT and TG contributed to the interpretation of the data from the literature, collected, analyzed and interpreted the data corresponding to the patient and critically revised the manuscript. AI collected, analyzed and interpreted the data corresponding to the patient and critically revised the manuscript. All authors read and approved the final manuscript for publication.

\section{Ethics approval and consent to participate}

The Ethics Committee of the National Institute of Mother and Child Care (Bucharest, Romania) (no. 25/2019) approved the study.

\section{Patient consent for publication}

Patient consent for publication was obtained and signed by the patient on 11/05/2019.

\section{Competing interests}

The authors declare that they have no competing interests.

\section{References}

1. Goldszmidt E, Kern R, Chaput A and Macarthur A: The incidence and etiology of postpartum headaches: A prospective cohort study. Can J Anaesth 52: 971-977, 2005.

2. Gonzalez JG, Elizondo G, Saldivar D, Nanez H, Todd LE and Villarreal JZ: Pituitary gland growth during normal pregnancy: An in vivo study using magnetic resonance imaging. Am J Med 85: 217-220, 1988

3. Chestnut DH, Wong CA, Tsen LC, Kee WDN, Beilin Y and Mhyre J: Postpartum Headache. Obstetric Anesthesia, Principles and Practice 5th edition. Philadelphia, Elsevier, pp713-718, 2014.

4. Bachmeier CA, Snell C and Morton A: Visual loss in pregnancy. BMJ Case Rep 12: e228323, 2019.

5. Freda PU, Beckers AM, Katznelson L, Molitch ME, Montori VM, Post KD and Vance ML; Endocrine Society: Pituitary incidentaloma: An endocrine society clinical practice guideline. J Clin Endocrinol Metab 96: 894-904, 2011.

6. Molitch ME: Diagnosis and treatment of pituitary adenomas: A Review. JAMA 317: 516-524, 2017.

7. Grand'Maison S, Weber F, Bédard MJ, Mahone $M$ and Godbout A: Pituitary apoplexy in pregnancy: A case series and literature review. Obstet Med 8: 177-183, 2015. 
8. Vandeva S, Jaffrain-Rea ML, Daly AF, Tichomirowa M, Zacharieva $S$ and Beckers A: The genetics of pituitary adenomas. Best Pract Res Clin Endocrinol Metab 24: 461-476, 2010.

9. Piantanida E, Gallo D, Lombardi V, Tanda ML, Lai A, Ghezzi F, Minotto R, Tabano A, Cerati M, Azzolini C, et al: Pituitary apoplexy during pregnancy: A rare, but dangerous headache. J Endocrinol Invest 37: 789-797, 2014

10. de Heide LJ, van Tol KM and Doorenbos B: Pituitary apoplexy presenting during pregnancy. Neth J Med 62: 393-396, 2004.

11. Abbassi-Ghanavati M,Greer LG and Cunningham FG: Pregnancy and laboratory studies: A reference table for clinicians. Obstet Gynecol 114: 1326-1331, 2009.

12. Ranabir S and Baruah MP: Pituitary apoplexy. Indian J Endocrinol Metab 15 (Suppl 3): S188-S196, 2011.

13. Krull I, Christ E, Kamm CP, Ganter C and Sahli R: Hyponatremia associated coma due to pituitary apoplexy in early pregnancy: A case report. Gynecol Endocrinol 26: 197-200, 2010.

14. Lee JS, Park YS, Kwon JT, Nam TK, Lee TJ and Kim JK: Radiological apoplexy and its correlation with acute clinica presentation, angiogenesis and tumor microvascular density in pituitary adenomas. J Korean Neurosurg Soc 50: 281-287, 2011.

15. Eastwood AK and Mohan AR: Imaging in pregnancy. Obstetrician Gynaecol 21: 255-262, 2019.

16. Janssen NM, Dreyer K and van der Weiden RM: Management of pituitary tumour apoplexy with bromocriptine in pregnancy. JRSM Short Rep 3: 43, 2012.

17. Oguz SH, Soylemezoglu F, Dagdelen S and Erbas T: A case of atypical macroprolactinoma presenting with pituitary apoplexy during pregnancy and review of the literature. Gynecol Endocrinol 36: 109-116, 2020.

18. Atmaca A, Dagdelen S and Erbas T: Follow-up of pregnancy in acromegalic women: Different presentations and outcomes. Exp Clin Endocrinol Diabetes 114: 135-139, 2006.

19. Lunardi P, Rizzo A, Missori P and Fraioli B: Pituitary apoplexy in an acromegalic woman operated on during pregnancy by transphenoidal approach. Int J Gynaecol Obstet 34: 71-74, 1991.

20. Paech MJ: An unusual presentation of a pituitary tumour in the early postpartum period. Anaesth Intensive Care 34: 79-82, 2006

21. Okafor UV, Onwuekwe IO and Ezegwui HU: Management of pituitary adenoma with mass effect in pregnancy: A case report. Cases J 2: 6350, 2009.

22. Abraham RR, Pollitzer RE, Gokden M and Goulden PA: Spontaneous pituitary apoplexy during the second trimester of pregnancy, with sensory loss. BMJ Case Rep 2016: bcr2015212405, 2016 .

23. Freeman R, Wezenter B, Silverstein M, Kuo D, Weiss KL, Kantrowitz $\mathrm{AB}$ and Schubart UK: Pregnancy-associated subacute hemorrhage into a prolactinoma resulting in diabetes insipidus. Fertil Steril 58: 427-429, 1992.

24. Ginath $S$ and Golan A: Images in clinical medicine. Gestational pituitary-tumor apoplexy. N Engl J Med 363: e10, 2010.

25. Gondim J, Ramos Júnior F, Pinheiro I, Schops M and Tella Júnior OI: Minimally invasive pituitary surgery in a hemorrhagic necrosis of adenoma during pregnancy. Minim Invasive Neurosurg 46: 173-176, 2003

26. Hayes AR, O'Sullivan AJ and Davies MA: A case of pituitary apoplexy in pregnancy. Endocrinol Diabetes Metab Case Rep 2014: 140043, 2014.

27. Jemel M, Kandara H, Riahi M, Gharbi R, Nagi S and Kamoun I: Gestational pituitary apoplexy: Case series and review of the literature. J Gynecol Obstet Hum Reprod 48: 873-881, 2019.

28. Kita D, Hayashi Y, Sano H, Takamura T, Hayashi Y, Tachibana O and Hamada J: Postoperative diabetes insipidus associated with pituitary apoplexy during pregnancy. Neuro Endocrinol Lett 33: 107-112, 2012

29. Lamberts SW, Klijn JG, de Lange SA, Singh R, Stefanko SZ and Birkenhäger JC: The incidence of complications during pregnancy after treatment of hyperprolactinemia with bromocriptine in patients with radiologically evident pituitary tumors. Fertil Steril 31: 614-649, 1979.

30. Lee MS and Pless M: Apoplectic lymphocytic hypophysitis. Case report. J Neurosurg 98: 183-185, 2003.
31. O'Donovan PA, O'Donovan PJ, Ritchie EH, Feely $\mathrm{M}$ and Jenkins DM: Apoplexy into a prolactin secreting macroadenoma during early pregnancy with successful outcome. Case report. Br J Obstet Gynaecol 93: 389-391, 1986.

32. O'Neal MA: Headaches complicating pregnancy and the postpartum period. Pract Neurol 17: 191-202, 2017.

33. Perotti V and Dexter M: Post-partum pituitary apoplexy with bilateral third nerve palsy and bilateral carotid occlusion. J Clin Neurosci 17: 1328-1330, 2010.

34. Querol Ripoll R, Cámara Gómez R, Del Olmo García M, Simal Julián JA and Merino Torres JF: Pituitary apoplexy in a pregnant woman with cystic microprolactinoma. Endocrinol Nutr 62: 200-202, 2015 (In Spanish).

35. Witek P, Zieliński G, Maksymowicz M and Zgliczyński W: Transsphenoidal surgery for a life-threatening prolactinoma apoplexy during pregnancy. Neuro Endocrinol Lett 33: 483-488, 2012.

36. Annamalai AK, Jeyachitra G, Jeyamithra A, Ganeshkumar M, Srinivasan KG and Gurnell M: Gestational pituitary apoplexy. Indian J Endocrinol Metab 21: 484-485, 2017.

37. Bamfo JE, Sharif S, Donnelly T, Cohen MA and Golara M A case of pituitary apoplexy masquerading as hyperemesis gravidarum. J Obstet Gynaecol 31: 662, 2011.

38. Chegour $\mathrm{H}$ and El Ansari N: Pituitary apoplexy during pregnancy. Pan Afr Med J 17: 211, 2014.

39. Couture N, Aris-Jilwan N and Serri O: Apoplexy of a microprolactinoma during pregnancy: Case report and review of literature. Endocr Pract 18: e147-e150, 2012.

40. Iuliano S and Laws ER Jr: Management of pituitary tumors in pregnancy. Semin Neurol 31: 423-428, 2011.

41. Parihar V, Yadav YR and Sharma D: Pituitary apoplexy in a pregnant woman. Ann Indian Acad Neurol 12: 54-55, 2009.

42. Watson V: An unexpected headache: Pituitary apoplexy in a pregnant woman on anticoagulation. BMJ Case Rep 2015: bcr2015210198, 2015.

43. Fujimaki T, Hotta S, Mochizuki T, Ayabe T, Matsuno A, Takagi K, Nakagomi T and Tamura A: Pituitary apoplexy as a consequence of lymphocytic adenohypophysitis in a pregnant woman: A case report. Neurol Res 27: 399-402, 2005.

44. Murao K, Imachi H, Muraoka T and Ishida T: Hemolysis, elevated liver enzymes, and low platelet count (HELLP) syndrome with pituitary apoplexy. Fertil Steril 96: 260-261, 2011.

45. Tonda C and Rizvi AA: Headache, pituitary lesion and panhypopituitarism in a pregnant woman: Tumor, apoplexy or hypophysitis? Am J Med Sci 342: 247-249, 2011.

46. Galvao A, Gonçalves D, Moreira M, Inocêncio G, Silva C and Braga J: Prolactinoma and pregnancy-a series of cases including pituitary apoplexy. J Obstet Gynaecol 37: 284-287, 2017.

47. De Ycaza AE, Chang AY, Jensen JR, Khan Z and Erickson D: Approach to the management of rare clinical presentations of macroprolactinomas in reproductive-aged women. Case Rep Womens Health 8: 9-12, 2015.

48. Bedford J, Dassan P, Harvie M and Mehta S: An unusual cause of headache in pregnancy. BMJ 351: h4681, 2015.

49. Tandon A, Alzate J, LaSala P and Fried MP: Endoscopic endonasal transsphenoidal resection for pituitary apoplexy during the third trimester of pregnancy. Surg Res Pract 2014: 397131, 2014.

50. Gheorghiu ML, Chirita C and Coculescu M: Partial remission of Nelson's syndrome after pituitary apoplexy during pregnancy. Society for Endocrinology BES 2009 Harrogate, UK Endocrine, Abstracts 19 P191, 2019.

51. Mathur D, Lim LF, Mathur M and Sng BL: Pituitary apoplexy with reversible cerebral vasoconstrictive syndrome after spinal anaesthesia for emergency caesarean section: An uncommon cause for postpartum headache. Anaesth Intensive Care 42: 99-105, 2014

52. Rajasekaran S, Vanderpump M, Baldeweg S, Drake W, Reddy N, Lanyon M, Markey A, Plant G, Powell M, Sinha S and Wass J: UK guidelines for the management of pituitary apoplexy. Clin Endocrinol (Oxf) 74: 9-20, 2011. 